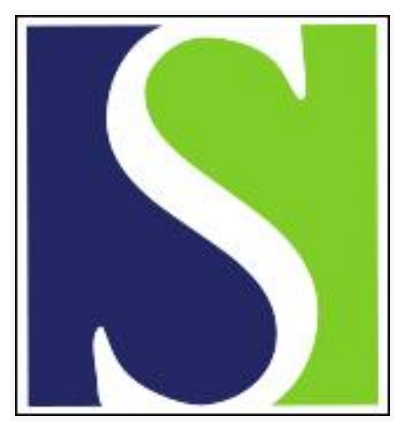

Scand J Work Environ Health 1995;21(3):191-198

https://doi.org/10.5271/sjweh.27

Issue date: Jun 1995

Pregnancy-related sickness absence among employed women in a Swedish county

by Alexanderson K, Hensing G, Carstensen J, Bjurulf P

The following articles refer to this text: 2013;39(4):321-323;

2015;41(2):184-193; 2015;41(4):397-406

Key terms: epidemiology; occupation; pregnancy; sick leave; woman

This article in PubMed: www.ncbi.nlm.nih.gov/pubmed/7481606

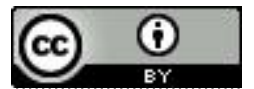




\title{
Pregnancy-related sickness absence among employed women in a Swedish county
}

\author{
by Kristina Alexanderson, BSocSc, ${ }^{1}$ Gunnel Hensing, BSocSc, ${ }^{1}$ John Carstensen, PhD, ${ }^{2}$ Per Bjurulf, PhD
}

\begin{abstract}
Alexanderson K, Hensing G, Carstensen J, Bjurulf P. Pregnancy-related sickness absence among employed women in a Swedish county. Scand J Work Environ Health 1995;21:191- 8.

Objectives The objective of this study was to analyze the variation of pregnancy-related sickness absence among employed women according to age, occupation, and degree of male-female domination within occupations.

Methods Data from a prospective study of all new sick-leave spells exceeding $7 \mathrm{~d}$ in 1985 and 1986 in the county of Östergötland, Sweden, were related to the population at risk, through the Swedish Medical Birth Register. The subjects included in the analysis were all 7000 employed women that gave birth in 1985 and 1986, of which some 3000 were sick-listed at least once with pregnancy-related diagnoses.

Results There was little difference in the pregnancy-related sickness absence between the age groups. The age-standardized rate for sick leaves involving pregnancy-related diagnoses differed substantially between occupations. Women in the metal industry had the highest rates; those employed in administration, banking, and insurance had the lowest. White-collar occupations generally had lower rates and blue-collar occupations higher rates, with some exceptions (eg, in saw mills, farming, and the chemical industry). Gender-integrated occupations had the lowest sick-leave rate, while extremely male-dominated jobs had the highest. The latter association remained after adjustment for occupational area.

Conclusions There were considerable differences between occupational groups in the rates of sick leaves involving pregnancy-related diagnoses. Some differences were related to physical load of the jobs being done, but not all. It seems important to consider also male-female domination within a job with respect to such sick leaves.
\end{abstract}

Key words epidemiology, occupation, pregnancy, sick leave, women.

Increasing sickness absence during pregnancy is a phenomenon acknowledged in Sweden $(1,2)$, as well as in other countries (3-5).

In the whole western world women's employment has undergone great changes since 1950 , especially so in the upper classes where the frequency of employment has risen the most (6). More women tend both to work during pregnancy and to remain in work longer during pregnancy than previously (6-9).

Employed and unemployed women differ in pregnancy outcome (10). Contrary to what could be postulated, unemployed women and housewives seem to be the risk group $(9,11-14)$. Corresponding systematic differences between employed and unemployed women have been reported in other studies $(10,12,15,16)$, and these differences are probably due to selection mechanisms. In a large study in the United States, it was found that "housewives were more likely to be on welfare and to smoke, and less likely to be married, college educated and white [p 416]" (15). From this perspective, it would be an advantage to study employed women in a country where employment is the norm. Sweden has the highest female employment rate, $85 \%$, in the western world, and therefore the healthy worker effect among the employed is negligible. On the other hand, it is probably very large in a negative way among the few Swedish unemployed women.

Although there are several studies on the effects of employment, education, social status, social network, and the like on pregnancy outcome $(5,6,14,15,17-19)$, only a few have examined how these factors are related to the pregnant women's health (20-25). Many studies focus on mental health $(23,26,27)$. Knowledge of how maternal health is reflected in sickness absence during

Department of Community Medicine, University Hospital, Linköping, Sweden.

Department of Health and Society, Linköping University, Linköping, Sweden.

Reprint requests to: Ms Kristina Alexanderson, Department of Community Medicine, University Hospital, 58185 Linköping, Sweden. 
pregnancy is scarce. Studies from France (3) and the Nordic countries (2) show high sick-listing, especially among women with physically heavy jobs $(4,28,29)$. More knowledge is needed about this phenomenon and its consequences.

The aim of this study was to analyze pregnancyrelated sickness absence among employed women and its relation to age and occupation. In a previous study we have shown that sickness absence, irrespective of diagnosis, varies according to male-female domination within occupations. The group of gender-integrated occupations had a low sick-leave rate; the group extremely male-dominated had a very high sick-leave rate (30). It could be expected that pregnancy-related sickness absence varied in a similar way.

\section{Subjects and methods}

The study covered all 400000 inhabitants in the county of Östergötland, approximately 5\% of Sweden's total population. Östergötland, located in the southeast of Sweden, is an expanding, highly industrialized area with both urban and rural municipalities. The county can be considered representative of at least southern Sweden, where $85 \%$ of the population lives (31). All employed persons are covered by national sickness insurance that covers work incapacity due to disease, injury or illness, not confinement, maternity or parental leave. Self-certification is accepted for the first $7 \mathrm{~d}$ of a period of sick leave.

During 1985, 1986, and 1987 all new sick leaves exceeding $7 \mathrm{~d}$ were recorded in the county of Östergötland, Sweden $(30,32)$. With each sick leave, some demographic variables were registered, including gender, age, occupation (33), and sick-leave diagnosis (34). Each sick leave was followed until its end or, at the longest, until September 1 st the following year. The dropout rate in the recording of the sick leaves was $15 \%$ in 1985 and 1987, 12\% in 1986 (30). Some 45000 persons were recorded with a total of 61000 sick leaves during 1985 , 1986 and 1987 (30).

Occupations recorded on the sickness certificates were coded according to the Nordic Occupational Classification, on a two-digit level, and assembled into 30 groups (33). The accordance and the coding of the diagnoses were tested, and they proved to be acceptable (35).

\section{Pregnancy-related diagnoses}

From the data base thus created, we selected data on all gainfully employed (employed and self-employed) women, aged 16-44 years and sick-listed with pregnancyrelated diagnoses in 1985 and 1986. Sick-listing with any of the following diagnoses on the sickness certificate were included: diagnosis number 634R, 635 and 637, according to the Nordic Medico-Statistical Committee (34), that is, toxemia, bleeding, urinary infections during pregnancy and abortion, early labor, and backache and fatigue due to pregnancy.

The population at risk, the denominator data, was obtained from the Medical Birth Register of the National Board of Health and Welfare, Sweden, in 1985 and 1986. The Register includes data on all newborn children and their mothers in Sweden. It was linked for 1985 and 1986 to the Swedish Official Population and Housing Census of 1985 and thus contained data on the number of women that gave birth in different occupations in the county of Östergötland.

\section{Statistics}

In order to increase precision in the results, the figures from 1985 and 1986 were combined. The sick-leave rate was expressed as the number of women within an occupation who had had at least one sick leave exceeding $7 \mathrm{~d}$ divided by the number of women that gave birth in that occupation.

The F-test was used to test the differences in the mean number of absence days between occupations. The sick-leave rates used in the comparison of and in the analysis of male-female domination in occupation were standardized for age through direct standardization with the total female employed population of Östergötland that gave birth as the standard. For the analysis concerning the different occupations, indirect standardization was used, since there were no births in some of the age groups for some occupations. A multiple logistic regression analysis was performed in order to separate the effects of age, occupational group, and degree of malefemale domination of occupations.

\section{Results}

In table 1, pregnancy-related sickness absence is shown for three age groups. Of the women aged 16-44 years that were certified as sick, $9 \%$ had pregnancy-related diagnoses. Most of the employed women (63\%) who gave birth were in the age group of 25-34 years; only $11 \%$ were aged $35-44$ years.

\section{Differences between occupations}

We have used a very rough classification of industrial types. Table 2 presents the sick-leave rate for different types of economic activity according to the Nordic Occupational Classification at a one-digit level (33). The 
Table 1. Pregnancy-related sickness absence in 1985-1986 among employed women aged 16-44 years.

\begin{tabular}{|c|c|c|c|c|c|c|c|}
\hline \multirow[t]{2}{*}{ Age } & \multirow{2}{*}{$\begin{array}{l}\text { Women } \\
\text { employed } \\
\text { (N) }\end{array}$} & \multirow{2}{*}{$\begin{array}{l}\text { Women } \\
\text { sick-listed } \\
\text { (N) }\end{array}$} & \multirow{2}{*}{$\begin{array}{l}\text { Women } \\
\text { giving birth } \\
\text { (N) }\end{array}$} & \multicolumn{2}{|c|}{ Sick-leave rate } & \multicolumn{2}{|c|}{$\begin{array}{l}\text { Sick-leave days per } \\
\text { sick-listed pregnant woman }\end{array}$} \\
\hline & & & & Rate $^{a}$ & $\begin{array}{c}95 \% \\
\text { confidence } \\
\text { interval }\end{array}$ & Mean & $\begin{array}{c}95 \% \\
\text { confidence } \\
\text { interval }\end{array}$ \\
\hline $\begin{array}{l}16-24 \text { years } \\
25-34 \text { years } \\
35-44 \text { years } \\
16-44 \text { years }\end{array}$ & $\begin{array}{l}12776 \\
19692 \\
23919 \\
56387\end{array}$ & $\begin{array}{r}672 \\
1542 \\
314 \\
2548\end{array}$ & $\begin{array}{r}1796 \\
4376 \\
761 \\
6933\end{array}$ & $\begin{array}{l}0.37 \\
0.35 \\
0.41 \\
0.37\end{array}$ & $\begin{array}{l}0.35-0.39 \\
0.34-0.36 \\
0.37-0.44 \\
0.36-0.38\end{array}$ & $\begin{array}{l}44.7 \\
46.1 \\
48.6 \\
46.0\end{array}$ & $\begin{array}{l}41.6-47.8 \\
44.2-48.0 \\
43.3-53.8 \\
44.4-47.6\end{array}$ \\
\hline
\end{tabular}

a According to the Swedish Official Population and Housing Census of 1985.

b Sick-leave rate = number of women sick-listed for pregnancy-related diagnoses divided by the number of women that give birth.

Table 2. Pregnancy-related sickness absence in various types of economic activity.

\begin{tabular}{|c|c|c|c|c|c|c|}
\hline \multirow[t]{2}{*}{ Type of economic activity } & \multirow{2}{*}{$\begin{array}{l}\text { Women } \\
\text { sick-listed } \\
(N)\end{array}$} & \multirow{2}{*}{$\begin{array}{c}\text { Women } \\
\text { giving birth } \\
(\mathbb{N})\end{array}$} & \multirow[t]{2}{*}{$\begin{array}{l}\text { Sick-leave } \\
\text { rate }\end{array}$} & \multirow{2}{*}{$\begin{array}{c}95 \% \\
\text { confidence } \\
\text { interval }\end{array}$} & \multicolumn{2}{|c|}{$\begin{array}{c}\text { Sick-leave days/sick-listed } \\
\text { pregnant woman }\end{array}$} \\
\hline & & & & & Mean & $\begin{array}{c}95 \% \\
\text { confidence } \\
\text { interval }\end{array}$ \\
\hline Professional work & 344 & 1144 & 0.29 & $0.26-0.32$ & 41.3 & $37.7-44.9$ \\
\hline Health care or social work & 1046 & 2621 & 0.40 & $0.38-0.42$ & 48.7 & $46.0-51.3$ \\
\hline Administration & 305 & 1038 & 0.30 & $0.27-0.33$ & 40.2 & $36.5-43.9$ \\
\hline Commercial work & 134 & 363 & 0.37 & $0.32-0.42$ & 42.3 & $36.0-48.7$ \\
\hline Farming & 27 & 111 & 0.24 & $0.16-0.32$ & 43.2 & $27.7-58.6$ \\
\hline Transportation communication & 48 & 176 & 0.27 & $0.21-0.33$ & 49.4 & $36.3-62.6$ \\
\hline Industrial work & 344 & 782 & 0.44 & $0.40-0.48$ & 47.8 & $43.2-52.5$ \\
\hline Service work & 287 & 679 & 0.43 & $0.39-0.47$ & 47.2 & $42.5-52.0$ \\
\hline Various & 13 & 19 & 0.64 & $0.54-0.74$ & 56.2 & $27.9-84.6$ \\
\hline
\end{tabular}

a Age-adjusted through direct standardization.

group composed of all the industrial jobs had a high sickleave rate for pregnancy-related diagnoses. Farming and transportation had the lowest rates, even lower than professional work. The group "various" consisted of small and often odd occupational groups like people employed in amusements parks, oil drilling, sports, precision-tool making, or engineering works. The mean number of absence days per sick-listed woman varied significantly between the different groups $(\mathrm{P}<0.05)$. There was also a tendency for the groups with a higher sick-leave rate to have a higher number of sickness absence days per sicklisted woman.

In table 3, the standardized sick-leave rates of the occupational groups are shown at a more-detailed level. The rates differed much between the different occupational groups. Women in the metal industry, where more than 1000 women aged 16-44 years worked, had a substantially increased pregnancy-related sick-leave rate. Low rates overall and in all age groups were found among women working within administration, advertisement, banking, and saw mills. Jobs demanding higher education, like engineers, teachers, or lawyers, had average or low rates.

Occupations with a high sick-leave rate for pregnancy-related diagnoses also had high sick-leave rates irrespective of diagnosis and vice versa. Saw mills and car- pentry were the only exceptions. Furthermore, the pregnancy-related sick-leave rate was higher than the rate irrespective of diagnosis in all occupations, especially so in cleaning and social work. Only the food industry, the chemical process industry, and saw mills or carpentry had lower rates of pregnancy-related diagnoses. Many women aged $16-44$ years are employed in social work $(\mathrm{N}=10181)$ and health work $(\mathrm{N}=7742)$; nearly $40 \%$ of the women that gave birth were employed within these groups.

In the following occupations the share of women giving birth before 25 years of age was considerably lower than average: engineering, teaching, legal professions, administrative work, banking, police work, and farming. For all of these the sick-leave rate was well below the average. Except for farming, they all demand higher education.

In the occupations in which a larger proportion gave birth below 25 years of age, we found no such uniform pattern concerning sick leaves. Instead these rates varied greatly, from 0.24 to 0.87 .

\section{Male-female domination in occupations}

Table 4 presents the results of the analysis of the sickleave rates when the occupations were assembled into 
Table 3. Pregnancy-related sickness absence in different occupations.

\begin{tabular}{|c|c|c|c|c|}
\hline \multirow[t]{2}{*}{ Occupation } & \multirow{2}{*}{$\begin{array}{l}\text { Women } \\
\text { sick-listed } \\
\text { (N) }\end{array}$} & \multirow{2}{*}{$\begin{array}{l}\text { Women } \\
\text { giving birth } \\
\text { (N) }\end{array}$} & \multicolumn{2}{|c|}{ Sick-leave rate } \\
\hline & & & Rate $^{a, b}$ & $\begin{array}{c}95 \% \\
\text { confidence } \\
\text { interval }\end{array}$ \\
\hline Metal industry & 126 & 144 & 0.87 & $0.81-0.93$ \\
\hline Various & 13 & 19 & 0.68 & $0.45-0.92$ \\
\hline Paper and pulp industry & 10 & 15 & 0.67 & $0.40-0.94$ \\
\hline Crane and excavatoring work & 5 & 8 & 0.62 & $0.24-0.99$ \\
\hline Painting, etc & 3 & 6 & 0.50 & $0.05-0.95$ \\
\hline Food industry & 28 & 56 & 0.50 & $0.35-0.64$ \\
\hline Textile industry & 25 & 52 & 0.48 & $0.33-0.63$ \\
\hline Cleaning & 131 & 278 & 0.47 & $0.40-0.53$ \\
\hline Transportation & 14 & 30 & 0.47 & $0.27-0.67$ \\
\hline Social work & 461 & 1005 & 0.46 & $0.43-0.49$ \\
\hline Hotel and restaurant work & 118 & 288 & 0.41 & $0.35-0.47$ \\
\hline Sales & 130 & 338 & 0.38 & $0.33-0.44$ \\
\hline Secretarial and clerical work & 216 & 585 & 0.37 & $0.33-0.41$ \\
\hline Health work & 585 & 1616 & 0.36 & $0.34-0.39$ \\
\hline Hairdressing and laundry work & 31 & 91 & 0.34 & $0.23-0.45$ \\
\hline Electrical work & 82 & 259 & 0.32 & $0.25-0.38$ \\
\hline Firefighting and police work & 7 & 22 & 0.32 & $0.10-0.54$ \\
\hline Teaching & 259 & 839 & 0.31 & $0.27-0.34$ \\
\hline Printing & 16 & 52 & 0.31 & $0.17-0.45$ \\
\hline Chemical processing & 22 & 73 & 0.30 & $0.18-0.42$ \\
\hline Engineering & 56 & 201 & 0.28 & $0.21-0.35$ \\
\hline Legal professions, clergy & 29 & 104 & 0.28 & $0.18-0.37$ \\
\hline Storage work & 24 & 101 & 0.24 & $0.14-0.33$ \\
\hline Farming and forestry & 27 & 111 & 0.24 & $0.15-0.33$ \\
\hline Post, telecommunications, etc & 34 & 146 & 0.23 & $0.16-0.31$ \\
\hline Saw mill and carpentry & 3 & 15 & 0.20 & $0.00-0.43$ \\
\hline Banking and insurance & 48 & 246 & 0.20 & $0.14-0.25$ \\
\hline Administration & 41 & 207 & 0.20 & $0.14-0.26$ \\
\hline Advertisement & 4 & 25 & 0.16 & $0.00-0.32$ \\
\hline Construction & - & 1 & & 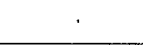 \\
\hline All employed women & 2548 & 6933 & 0.37 & $0.36-0.38$ \\
\hline
\end{tabular}

a Age-adjusted through indirect standardization.

b Sick-leave rate $=$ the rate of pregnant women sick-listed with pregnancy-related diagnoses.

Table 4. Pregnancy-related sickness absence according to degree of male-female domination in occupations.

\begin{tabular}{|c|c|c|c|c|c|}
\hline \multirow[t]{2}{*}{ Type of gender dominationa } & \multirow{2}{*}{$\begin{array}{c}\text { Women } \\
\text { in occupation } \\
(\%)\end{array}$} & \multirow{2}{*}{$\begin{array}{l}\text { Women } \\
\text { sick-listed } \\
\text { (N) }\end{array}$} & \multirow{2}{*}{$\begin{array}{l}\text { Women } \\
\text { giving birth } \\
\text { (N) }\end{array}$} & \multicolumn{2}{|c|}{ Sick-leave rate } \\
\hline & & & & Rate $^{b}$ & $\begin{array}{c}95 \% \\
\text { confidence } \\
\text { interval }\end{array}$ \\
\hline $\begin{array}{l}\text { Extremely male-dominated jobs } \\
\text { Male-dominated jobs } \\
\text { Gender-integrated jobs } \\
\text { Female-dominated jobs } \\
\text { Extremely female-dominated jobs }\end{array}$ & $\begin{array}{c}0-10 \\
0-40 \\
40-60 \\
60-100 \\
90-100\end{array}$ & $\begin{array}{r}158 \\
440 \\
282 \\
1887 \\
677\end{array}$ & $\begin{array}{r}226 \\
1138 \\
1041 \\
4754 \\
1590\end{array}$ & $\begin{array}{l}0.69 \\
0.38 \\
0.27 \\
0.38 \\
0.42\end{array}$ & $\begin{array}{l}0.63-0.75 \\
0.35-0.41 \\
0.24-0.30 \\
0.37-0.39 \\
0.40-0.44\end{array}$ \\
\hline
\end{tabular}

a Percentage of women: extremely male-dominated jobs: transportation and communication $7 \%$, metal industry $9 \%$, sawmill work $10 \%$, painting $3 \%$, construction $<1 \%$, crane and excavator work $6 \%$, firefighting and police work $9 \%$; male-dominated jobs: occupations and percentages listed for extremely male-dominated jobs plus engineering $12 \%$, advertising and purchasing $25 \%$, farming and forestry $18 \%$, electrical work $34 \%$, printing and graphics work $33 \%$, chemical processing $31 \%$, paper and pulp industry $16 \%$, storage work $32 \%$, various $21 \%$; genderintegrated jobs: administration $49 \%$, sales $53 \%$, legal profession $46 \%$, banking and insurance $45 \%$, post and telecommunications $59 \%$; femaledominated jobs: occupations and percentages listed under extremely female-dominated jobs plus health work $86 \%$, teaching $66 \%$, textile industry $72 \%$, hotel and restaurant work $84 \%$, cleaning $68 \%$, hairdressing and laundry work $82 \%$; extremely female-dominated jobs: social work $92 \%$, secretarial and clerical work $93 \%$.

Age-adjusted through direct standardization.

three groups according to the proportion of women employed within each occupational group. The male- and female-dominated occupations had average rates, whereas the gender-integrated occupations had low rates.
We also analyzed the extremely male- and extremely female-dominated occupations. Women employed in the extremely male-dominated group, consisting of occupations in which less than $10 \%$ of the employed were 
women, had the highest sick-leave rate. This group included heavy industry-type of occupations, but also others, like police work and bus and taxi driving. The group "various" was male-dominated, but not extremely so.

According to the logistic regression analysis, this difference was only due to a small extent to the fact that the jobs were from different industries according to the Nordic Occupational Classification on a one-digit level, and was still strongly significant ( $\mathrm{P}<0.0001$ ). The same differences in sick-leave rate according to gender segregation of jobs existed, for instance, within both the group "industrial work" and "transportation."

\section{Discussion}

The well-documented increasing sick-listing during pregnancy (2-4) in Sweden is parallel to a decrease in the use of parental leave before delivery (1). This could be understood as a coping strategy to save parental leave days until after the child is born. In spite of this general trend, we found large differences in the sick-leave rate between occupations. Some of these differences were expected, some not.

The study concerns the incidence of pregnancy-related sickness absence in a large, well-defined population. The officially recorded data of our study are probably more valid than the self-reported data from questionnaires that many studies of this type are based on. Furthermore, sickness absence is a multifactorial phenomenon affected by medical, psychological, social, and cultural factors, as well as by the social insurance system.

Most previous studies are not comparable to our findings due to large variations in the study design, coding of occupations, variations in national social security systems (36-38), female employment rate, and work conditions (15). Furthermore, our study covers sickness absence exceeding $7 \mathrm{~d}$ for pregnancy-related diagnoses, not short absences, absences with other diagnoses during pregnancy, or maternal or parental leave. Therefore our rates are lower than those of most other studies.

The time during a year that a woman is at risk of being absent because of sickness is shorter with pregnancy-related diagnoses than with other diagnoses. Nevertheless, the sick-leave rate was considerably higher for pregnancy-related diagnoses, 0.37 compared with 0.26 (30). However, the duration of sickness absence per sicklisted woman was shorter for the pregnancy-related diagnoses than for all the diagnoses leading to sickness absence, partly due to the shorter risk period, but also to the fact that delivery automatically brings an end to sick leave.
Age

From a medical perspective, a large increase in sickleave rate for pregnancy-related diagnoses with age could be anticipated. We did not find this trend, however. The relatively high rate of the younger women could be due to changing attitudes (2) or to the fact that younger women more often have jobs that are difficult to combine with pregnancy (4).

For occupations in which women had a higher age at delivery, one can postulate that these women either tend to have children later in life or that they were recorded as students when having their first child or children. Myllynen found the same pattern (14).

\section{Differences between occupations}

We have not found any other population-based study of sickness absence because of pregnancy in which occupations are presented on a more-detailed level. Other studies are either on a level comparable with the one-digit of the Nordic Occupational Classification (table 2) $(3,5,6$, $14,28,39,40$ ) or focus on one occupation (41).

Occupation does not reveal that much about the work conditions of the individual woman. However, SaurelCubizolles et al (5) has shown that occupation is a more reliable indicator of risk for preterm delivery than selfreported work conditions. Occupation was found to summarize both occupational and social conditions in a more discriminate way than either alone (5).

We found a higher sick-leave rate for pregnancyrelated diagnoses in physically more-demanding occupations. The rates for metal work were outstandingly high for these diagnoses, as was that for all diagnoses together (30). The situation of these women needs to be studied further.

Sick-leave rates were average or lower in physically less demanding jobs and also among those requiring higher education. This finding is in line with the results of most studies in this field $(3,28,29)$, except the one by Lundby et al (40), in which no differences between occupations were found. Furthermore, from different studies one can conclude that physically heavy jobs, low social support, age, immigrant status, and poverty often go together with poor health in pregnancy $(20,24-26)$ and that strenuous work conditions lead to increased sick leave $(3,29)$.

As both physicians and women are aware of the correlation between the aforementioned factors and increased sick leave during pregnancy, as well as of the negative influence these factors might have on pregnancy outcome, they both might favor sick listing $(10,42)$. On the whole, women are monitored more closely by medical staff during pregnancy than otherwise, which in itself might increase the "risk" of being sick-listed (43). 
Chamberlain (7) even claims that some women feel forced to be sick-listed by overprotective, male physicians. In this perspective, one of our most surprising results is that not all industrial or heavy jobs have high rates. For instance, saw mills, farming, the chemical industry, health work, firefighting work, and police work all had low or lower than average rates. In other words, the relatively low rate of the industrial jobs assembled at a one-digit-level according to the Nordic Occupational Classification is not in line with the conclusions of Saurel-Cubizolles \& Kaminski (29). Factors other than how heavy a job is also seem to predict sick-leave rates.

\section{Male- or female-dominated occupations}

The results of a wide range of public health studies, show that morbidity, mortality, and sickness absence vary with social status. To some extent, these variations can be explained by differences in health-related behavior, work characteristics, social support, and the like. However, most of the differences still remain to be explained (44). Maybe the numerical gender domination of occupations (45) is one factor to be considered in this context.

We found that the pregnancy-related sick-leave rate was much higher in the extremely male-dominated group and lowest in the gender-integrated group. This finding corresponds well with our findings of female sick-leave rate irrespective of diagnoses (30) and with minor psychiatric morbidity (46), as well as with Hall's finding of women's degree of work control in these areas. Where we found a high sick-leave rate, she found low work control, and vice versa (45). Our data does not provide an explanation for this correlation.

Additional factors might be important concerning pregnancy-related diagnoses. We know from other studies that social support is an important factor in the health of women (45), also during pregnancy (24). Routines, norms, and work organization formed to suit the male worker might be extra hard for a woman to adapt to when pregnant. It might also be more difficult for a woman to receive social support in an extremely maledominated job situation when pregnant. Furthermore, selection may occur among the women working there.

The reason for such a difference between the sickleave rates in the female-dominated and gender-integrated occupations is more difficult to explain from a perspective like ours. The gender-integrated jobs tended to demand more education, however. Brown has shown that women with more prestigious work tend to have less somatic symptoms and depression and greater wellbeing during pregnancy (24). However, all occupations demanding higher education, for example, teaching, did not have very low rates.

The variation in sick-leave rates was very large within the extremely male-dominated jobs, partly due to the fact that, by definition, there are very few women in some of them, but also because they were coded on a very detailed level in comparison with the female-dominated jobs (30). The fact that "male" jobs are coded at a more-detailed level than traditional "female" jobs is a problem in epidemiologic studies involving the gender perspective of the role of occupation.

\section{Need for a possibility of pregnancy leave}

Most women today do not work at the end of pregnancy, but quit work or take vacation, sick leave, or maternal or parental leave (39). The work cessation rate during pregnancy differs between nations, over time as well as with parity and occupation of the mother $(6,14,47)$. In Sweden this work cessation is mainly taken care of through sick listing (1). This procedure has several negative effects for the individual woman, the employers, physicians, social security administration, and also society as a whole. Many people have suggested a change in this situation, without a large impact on social insurance costs, through granting each woman some part- or fulltime "pregnancy-leave" weeks $(4,38,48)$ that could not be saved until after delivery.

As in most other studies on occupational effects on health, we have not taken the unpaid (domestic) work load of the woman into account $(10,49)$. This might vary much with parity $(10,21,23,50)$, age, social class, marital status (10), part- or full-time work, shift work, commuting time to work, social support $(23,24)$, nationality, previous health, and geographic situation. It would have been an advantage to include all of these variables in the analysis. However, our data did not allow it.

\section{Concluding remarks}

Sickness absence from pregnancy-related diagnoses is not clearly related to factors like age of the pregnant woman or physical heaviness of the work. However, occupation does matter. One explanation of the large differences in the sick-leave rates between occupations might be caused by gender issues rather than by more traditional variables such as physical heaviness. Further studies are needed.

\section{Acknowledgments}

This study was supported by the Swedish Council for Planning and Co-ordination of Research and by the Swedish Medical Research Council. 


\section{References}

1. Röcklinger A, Axe I. Undersökning av havandeskapspenningärenden [A study of maternal leave]. Stockholm: Riksförsäkringsverket, 1988.

2. Alexanderson $\mathrm{K}$, Hensing G, Leijon M, Åkerlind I, Rydh H, Bjurulf P. Pregnancy-related sickness absence in a Swedish county in 1985, 1986 and 1987. J Epidemiol Community Health 1994;48(5):464-70.

3. Mamelle N, Bertucat I, Munoz F. Pregnant women at work: rest periods to prevent preterm birth. Paediatric Perinatal Epidemiol 1989;(3):19-28.

4. Grünfeld B, Qvigstad E. Sykdom under svangerskapet [Sick leave among pregnant women in Oslo]. Tidsskr Nor Lœgeforen 1991;111(10):1269-72.

5. Saurel-Cubizolles MJ, Subtil D, Kaminski M. Is preterm delivery still related to physical working conditions in pregnancy? J Epidemiol Community Health 1991;45:29—34.

6. Saurel-Cubizolles MJ, Kaminski M. Work in pregnancy: its evolving relationship with perinatal outcome. Soc Sci Med 1986;22(4):431-2.

7. Chamberlain G. Women at work in pregnancy. In: Chamberlain G, editor. Pregnant women at work. London: The Royal Society of Medicine, 1984:3-13.

8. Chavkin W. Work and pregnancy: review of the literature and policy discussion. Obstet Gynecol Sur 1986;41(8):467-72.

9. Murphy JF, Dauncey M, Newcombe R. Employment in pregnancy: prevalence, maternal characteristics, perinatal outcome. Lancet 1984;1:1163-6.

10. Joffe M. Biases in research on reproduction and women's work. Int J Epidemiol 1985;14(1):118—23.

11. Saurell MJ, Kaminski M. Pregnant women at work. Lancet 1983;1:475.

12. Saurel-Cubizolles M-J, Gestin G. Housewives, unemployed and employed women: why different risks of preterm delivery?: a French study. Int J Health Sci 1991;2(2):83-91.

13. Najman J, Morrison J, Williams G, Keeping J, Anderson M. Unemployment and reproductive outcome: an Australian study. Br J Obstet Gynaecol 1989;96:308-13.

14. Myllynen L. Work during pregnancy [thesis]. Helsinki: University of Helsinki, 1991.

15. Marbury MC, Linn S, Monson RR, Wegman DH, Schoenbaum SC, Stubblefield PG, et al. Work and pregnancy. J Occup Med 1984;26(6):415-21.

16. Waldron I, Herold J, Dunn D, Staum R. Reciprocal effects of health and labor force participation among women: evidence from two longitudinal studies. J Occup Med 1982;24(2):12632.

17. Nurminen T, Kurppa K. Office employment, work with video display terminals and course of pregnancy. Scand J Work Environ Health 1988;14:293 - 8

18. McDonald AD, McDonald JC, Armstrong B, Cherry N, Delorme $\mathrm{C}$, Nolin AD, et al. Occupation and pregnancy outcome. Br J Ind Med 1987;44:521-26.

19. Oakley A. Social support in pregnancy: the 'soft' way to increase birthweight? Soc Sci Med 1985;21(11):1259-68.

20. Hall M. Health of pregnant women. Br Med J 1991;303(24): $460-2$.

21. Røssaak E, Jacobsen G. Helseforhold blant gravide [State of health among the pregnant]. Tidsskr Nor Lœgeforen 1987; 107(17-18):1578-9.

22. Gjerdingen DK, Froberg DG, Fontaine P. The effects of social support on women's health during pregnancy, labor and delivery, and the postpartum period. Fam Med 1991;23(5):370-5.
23. O'Hara MW. Social support, life events and depression during pregnancy and the puerperium. Arch Gen Psychiatry 1986;43: 569-73.

24. Brown MA. Employment during pregnancy: influences on women's health and social support. In: Swanson-Kaussman C, editor. Women's work, families, and health. Washington, DC: Hemisphere Publishing Corporation, 1987:151 67.

25. Carr-Hill RA, Thalin M, Johansson S. Pregnancy, social status and health in Sweden: research note. Soc Sci Med 1983;17(6): 343-7.

26. Gjerdingen DK, Froberg DG, Kochevar L. Changes in women's mental and physical health from pregnancy through six months postpartum. J Fam Pract 1991;32(2):161-6.

27. Wenda $\mathrm{K}$. The effects of social support on women's health during pregnancy, labor and delivery, and the postpartum period. Fam Med 1991;23(5):370—5.

28. MOR 88. En undersökning av gravida kvinnors sjukskrivning [An investigation of sickness absence of pregnant women in 1988]. Stockholm: Försäkringskassan, 1990.

29. Saurel-Cubizolles MJ, Kaminski M. Pregnant women's working conditions and their changes during pregnancy: a national study in France. Br J Ind Med 1987:44:236—43.

30. Alexanderson K, Leijon M, Akerlind I, Rydh H, Bjurulf P Epidemiology of sickness absence in a swedish county in 1985, 1986 and 1987. Scand J Soc Med 1994;22(1):27-34.

31. Folkhälsorapport för Östergötland 1993 [Public health in Östergötlan 1993]. Linköping: The County of Östergötland, 1993.

32. Bjurulf $\mathrm{P}$, Johansson $\mathrm{G}$, Ljungdahl L, Persson $\mathrm{H}$, Levin J-E, Åstrand G. Sjukskrivning i förhållande till diagnos och yrke 1985-1987 i Östergötlands län [Sickness absence in relation to diagnosis and occupation in the county of Östergötland, in 1985 to 1987]. Linköping: Department of Community Medicine, 1990

33. Nordisk yrkesklassificering [Nordic Occupational Classification]. Stockholm, Arbetsmarknadsstyrelsen, 1983.

34. Code-list for diagnoses used in ambulatory care. Stockholm: Nordic Medico-Statistical Committee, 1977.

35. Ljungdahl L, Bjurulf $\mathrm{P}$. The accordance of diagnoses in a computerized sick-leave register with doctor's certificates and medical records. Scand J Soc Med 1991;19(3):148-53.

36. Henrekson M, Lantto K, Persson M. Bruk och missbruk av sjukförsäkringen [Use and malingering of sickness absence] Stockholm: SNS förlag, 1992

37. Prins R, De Graaf A. Comparison of sickness absence in Belgian, German, and Dutch firms. Br J Ind Med 1986;43 $529-36$

38. Saurel-Cubizolles M-J, Romito P, Garcia J. Description of maternity rights for working women in France, Italy and in the United Kingdom. Eur J Public Health 1993;3:48-53.

39. Strand K, Wergeland E, Endresen EH, Bjerkedal T. Factors associated with work status of pregnant employees in Norway 1989. In: Wijma K, Schoultz von B, editors. Reproductive life: advances in research in psychosomatic obstetrics and gynaecology. Carnforth: The Panthenon Publishing Group, 1992:617-23

40. Lundby IH, Tellness G, Stray-Pedersen B. Graviditet og sykmelding [Pregnancy and sick-leave]. Tidsskr Nor Lœgeforen 1988;108(27):2291-4.

41. Kierkegaard O, Kristiansen J. Sygemelding i graviditeten med fokus på textilarbejdere [Sick-leave during pregnancy with special attention to textile workers]. Ugeskr Læger 1992 154(34):2306-8.

42. Paul JA, van Dijk FJH, Frings-Dresen MHW. Work load and 
musculoskeletal complaints during pregnancy. Scand J Work Environ Health 1994;20:153-9.

43. Spyckerelle Y, Trudel M, Deschamps JP. Grossesse et travail: à propos des arrêts de travail maladie. Rev Fr Gynécol Obstét 1989;84(11):743-6.

44. North F, Syme SL, Feeney A, Head J, Shipley M, Marmot MG. Explaining socioeconomic differences in sickness $a b-$ sence: the Whitehall II study. Br Med J 1993;306:361-6.

45. Hall EM. Women's work: an inquiry into the health effects of invisible and visible labor. Stockholm: Karolinska Institutet, 1990.

46. Hensing G, Alexanderson K, Akerlind I, Bjurulf P. Sickness absence in minor mental ilness: role of sex integration. Soc
Psychiatry Epidemiol 1994.

47. Jimenez MH, Newton N. Activity and work during pregnancy and the postpartum period: a cross-cultural study of 202 societies. Am J Obstet Gynecol 1979;135(2):171-6.

48. Ollson S-E. Kvinnor i arbete och reproduktion [Women in work and reproduction]. Lund: Bokbox, 1993.

49. Chamberlain G. Work in pregnancy. Br Med J 1991;302: $1070-3$.

50. Jacobsen G. Antenatal care in general practice, Trondheim, Norway. Scand J Prim Health Care 1989;(7):27-32.

Received for publication: 2 September 1994 